\title{
Experience of the Employment Relationship after a Merger
}

Mergers and acquisitions create many management challenges. The development of a new employment relationship is one of the problems in such a situation. This paper investigates the influence of previous employment structures and the experience of previous employment relationships on the psychological contract, job satisfaction, job insecurity, and general health of employees in the context of a merged higher education institution. Employees of two previously independent universities that merged into one university completed a questionnaire. The two former universities had a very different history with very dissimilar employment relationships and experiences among personnel. This history influenced the experience of the employment relationship after the merger.

Key words: Employment Relations, Mergers and Acquisitions, Work Wellness

* Bennie Linde, Work Well Research Unit for People, Policy and Performance, School of Human Resource Sciences, Faculty of Economic and Management Sciences, North-West University, South Africa, Contact details: Private Bag X6001, Potchefstroom, 2520, South Africa, e-mail: bsobjl@puk.ac.za, Internet: http://www.workwellness.co.za.

Professor René Schalk, Department of Organization Studies at Tilburg University in the Netherlands Contact details: PO Box 90153, 5000 LE Tilburg, The Netherlands, e-mail: m.j.d.schalk@uvt.nl, Internet: http://www.uvt.nl.

** Article received: April 11, 2006

Revised version accepted after double blind review: July 3, 2006. 


\section{Introduction}

Although a changing workplace is nothing new, the amount of radical changes and transformations of organizations seemed to escalate during the past few decades. Important phenomena in this respect are mergers and acquisitions. Although these are more prominent in the corporate landscape, they also occur in the public sector. Kode et al. (2003: 28) state, "internationally 96020 companies came under new management through mergers and acquisitions (worth \$3.4 trillion) from January 1990 to June 1997. It is estimated that in 1999 alone merger and acquisition activities rose worldwide by over one third from 1998 levels."

South Africa experienced 823 mergers and acquisitions in 2004, totaling $\$ 18,1$ billion, an increase of $15.4 \%$ over the previous year. The number of public sector mergers also showed a very substantial increase internationally in the past decade (International Merger and Acquisition Summit 2003). South Africa, for example, has seen 843 local municipalities being merged into 284 local governments in 2000 (Xundu 2000), and 36 higher education institutions were merged or incorporated into 21 new institutions in the years 2004 and 2005 (Ministry of Education 2003; Vergnani 2001). In these examples alone, an estimated 180000 employees were exposed to these types of transformations.

The numbers of mergers in the higher education sector in particular increased during recent decades (Kotecha/Harman 2001). In the words of Balmer and Dinnie (1999: 183), "Few sectors are immune to the wave of consolidation sweeping the global economy, impinging on both the private and public sectors." Schalk et al. (2001:1) refer to these rapid and "unpredictable changes as a consequence of the globalization of markets, the intensification of economic travel, growing competition, shortened life cycles of products and services and growing pressure to innovate."

The implication is that mergers and acquisitions form an integral part of today's workplace. The specific motivation for mergers differs, contingent on situation and sector. Whereas corporate mergers are generally motivated by a quick growth in revenue (even if it is by incorporating competition; Huang/Kleiner 2004), structural changes for better service efficiency is the most prominent cause for mergers in the public sector (Hackett 1996). The difference between a merger and an acquisition relates to the challenges managers of organizations experience, which may lead to such a transformation. Usually, a smaller company will be taken over by a stronger competitor in an acquisition.

The acquired company's staff have to adapt to the acquiring company's identity and culture. This process implies a one-sided transformation where the acquired company can use certain procedures to try and protect their rights, but at the discretion of the acquiring company. In case of a merger, which is the focus of this paper, the playing field is more complex and has more levels, since a new identity and culture are negotiated and created for the merged organization, even though in a merger there is always a more senior partner that will have a greater influence on the negotiation process (Balmer/Dinnie 1999: 182).

Whatever the reasons for mergers and acquisitions, the success rates are still being debated. Most academic research focusing on the outcomes of mergers identi- 
fies the financial successes (failures) and production outcomes. Though this paper focuses on mergers in the public sector, these results detail the influence of mergers on organizations and their employees. For example, based on merger statistics of leading business publications, Galpin and Herndon (2000: 2) conclude that:

- "Only 23 per cent of all acquisitions earn their cost of capital.

- In acquired companies, 47 per cent of executives leave within the first year, and 75 per cent leave within the first three years.

- In the first four to eight months that follow a deal, productivity may reduce by up to 50 per cent.

- Moreover, CEOs and CFOs routinely cite 'people' problems and cultural issues as the top factors in failed integrations."

This trend is also observed in other studies (see Adams/Neely 2000; Balmer/Dinnie 1999; Bert et al. 2003; Baxier et al. 2001: 6; Cartwright/Cooper 1996; Schraeder/Self 2003).

Rating the success of a merger, however, is not limited to financial expectations. The party who evaluates the merger will determine the measure of success. The shareholders of a company may use financial dividends to measure success, while the managers might look at sustainable growth and structural development. The employee's experience of merger success will be measured by the extent of employee wellness experienced, including job satisfaction and security, rewards, and occupational health and safety. In the case of a public sector merger, the level of community service will be the measure of success to the public. It is therefore much more difficult to identify the total level of success in the public sector than in the private sector.

This brings us to the question of which factors influence the success and failure rates of mergers and acquisitions. Here, we focus on the human factor. Classe (2004: 32) states: "Something that can be overlooked with takeovers and mergers is properly managing the human aspect of change. In other words: keeping the employees happy." Research has already been done about the individual's experience of organizational change, with specific focus on the influence of personal characteristics (see Porter et al. 2003; Stave et al. 2003; Maree/Eiselen 2004). In this paper, however, the focus is on the influence of the pre-merger employment structures and relationships on employees' experience of the "new" employment relationship. Therefore the purpose of this study is to identify how the employees experience their new employment relationship through the experience of the psychological contract, job satisfaction, job insecurity and general health after the merger of public sector institutions. In addition, the influence of the merger on the experience of the psychological contract, job insecurity, job satisfaction and general health of employees with different previous employment relationships with the pre-merged institutions will be determined.

To achieve these objectives, a brief literature review of the experience of the psychological contract, job satisfaction, job insecurity and general health by employees in a merger follows below. Thereafter an empirical report identifies the study population and samples, as well as the measures used, followed by results and discussions. 


\section{Employment relationships and mergers}

It might be that decision-makers base their expectations of the merger outcomes on the pre-merged productiveness of the workforces involved, without taking into account the negative influence of stress due to change, as well as the employmentrelated experiences that the "new" relationship inherits. Therefore mergers present a challenge to leaders who have to implement the change in ways that keep the employees motivated and positive. The cooperation of employees in the new organization is needed in a situation in which valued identities are threatened and may need to change. These observations of the experiences of mergers and acquisitions are linked to the psychological contract of the employees.

The psychological contract of employees, which refers to the experience of perceived promises made and kept (Rousseau 1995: 112), is not limited to the employment relationship associated with the acquiring organization, or the newly formed merged organization. Linde and Schalk (2005) showed that an "old" psychological contract can be inherited by a "new" employment relationship. This implies that the employee's perception of a breach of contract and experience of contract violation, associated with the employment relationship of the pre-merged organization, can automatically be included in the employment relationship of the merged organization. In addition, even in case of a good psychological contract in the "old" employment relationship, the action of merging can cause the experience of contract breach and violation.

Rousseau (1995: 112) defined this experience of breach and violation of the psychological contract as follows:

"In the strictest sense, breach refers to a failure to comply with the terms of a contract.

But, given the subjective nature of the psychological contract, how people interpret the circumstances of this failure determines whether they experience a violation."

Therefore a violation of the psychological contract refers to emotional and affective reactions such as those that may arise when the individual feels that the organization has failed to uphold properly its end of the psychological contract, for whatever reason (Morrison/Robinson 1997). More specifically, Schalk et al. (2001: 7) identify that a "violation of the psychological contract arises when the employee perceives a discrepancy between perceived obligations and promised obligations." Most employees perceive a promise made in the context of a permanent employment relationship to remain the same, without radical changes (Garrow 2003). Classe (2004: 32) explains that "if a change to the workplace is perceived as breaching the psychological contract, the violation can undermine employee commitment to the post-change organization, with disastrous impact on the bottom line."

Owing to mergers and acquisitions, the experience of breach and violation of the psychological contract will almost always increase, because a new contract is created, as well as new management, new colleagues and new formal and informal structures. One of the biggest contributors to these effects is the change of the institutional identity and culture. However, Balmer and Dinnie (1999), on the other hand, identify the establishment of a new institutional identity and communication as the possible solution to the experience of contract breach and violation. These researchers emphasize that thorough 
efforts need to be put into the establishment of structures, including employmentrelated policies, that encourage the development of a new institutional identity to prompt new common goals and rules. Such an identity has a crucial influence on the experience of the employment relationship before and after a merger, since it assists in identifying common structures and disciplinary boundaries for this relationship to change (Balmer/Dinnie 1999: 184). The employees' experience of these new structures, or the lack thereof, can thus contribute to the experience of the psychological contract and the short- and long-term reactions associated with it.

\section{Influence of the employment relationship on work wellness}

In the process of identifying the variables for measuring the influence of a merger on the establishment of a new employment relationship, the stress process model of Katz and Kahn (1978) was used as a guideline. As stated by Hellgren (2003: 24), this model describes the process in which the individual creates:

"a subjective or psychological conception of the objective reality, and it is this subjective interpretation which then triggers reactions - of a physiological, psychological and behavioural manner - that finally, in the last stage of this process, results in the development of mental and physical health complaints."

Furthermore, the individual's characteristics and the social context have moderating or stressing impacts on this process, finally influencing the short- and long-term reactions that the individual experiences. In the case of a merger of an organization or institution, the employees find themselves in a "new" employment relationship with a "new" employer (an objective condition). However, the influences of the merger and the pre-merger employment relationship (as social context influences) create the experience of the psychological contract (a subjective experience). The experience of this psychological contract, and especially the experience of breach and violation of the contract, can influence the experience of job satisfaction and job insecurity (being short-term reactions), which can lead to a long-term reaction in terms of the employee's wellbeing, including general health.

Figure 1 identifies these variables in an adapted model for the purpose of this study.

Figure 1: Adapted stress process model of Katz and Kahn, 1978 (Hellgren 2003: 24)

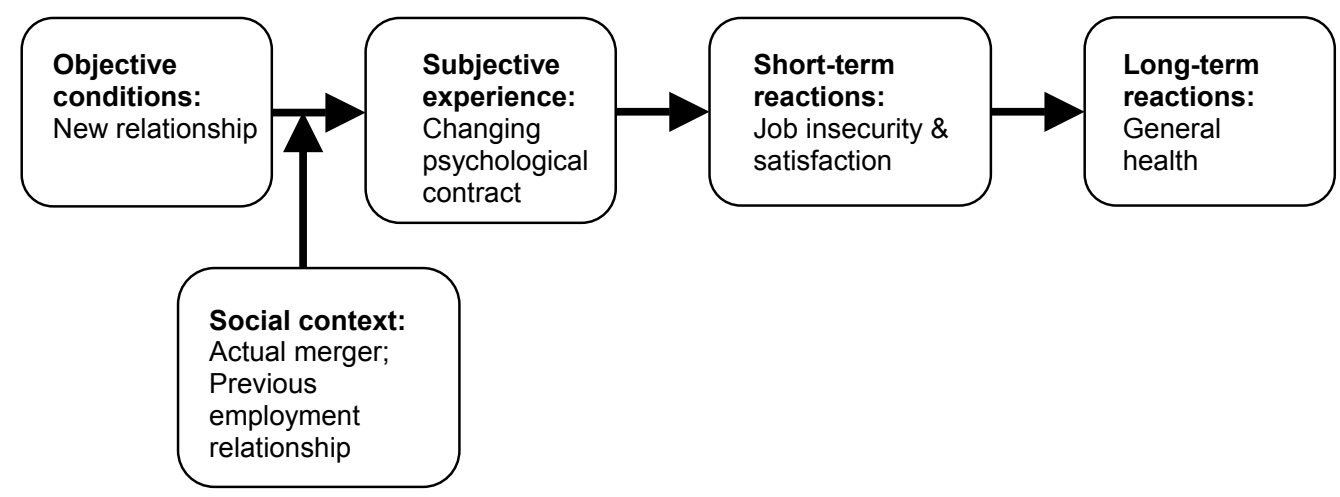


The influence of the individual characteristics of the employees (including gender, tenure, qualification, age etc.) can have a very prominent influence in the experience of a changing employment relationship during a merger. However, for the purpose of this paper, the focus will be on the collective experience of the psychological contract, job satisfaction, job insecurity and general health of employees from the different premerger organizations to identify the influence of previous employment structures and the merger thereon. Therefore the individual characteristics as variables are deliberately ignored.

When Figure 1 is examined in the mentioned context, where the variables are linked to this model, certain expected results can be identified, including that a different psychological contract will be experienced by the different groups associated with a merger. This may create different levels of job insecurity, where a psychological contract with high levels of contract breach can aggravate the experience of job insecurity and lower job satisfaction levels. These variables can also be influenced by the idea of merging itself. The long-term reactions of the employment relationship, being general health in this research, will probably also be different due to the previous employment relationships' various levels of work-related stress.

Therefore, through the use of these different variables, the different experiences of employment relationships can be linked to short- and long-term reactions, as well as the influence of the merger on them.

\section{Method}

\section{Participants}

The permanent personnel of a merged higher education institution (HEI) in South Africa were the subject of this study. The HEI is the product of a merger between two different and autonomous universities. The employment relationship regulations of the two former universities differed radically. Linde and Schalk (2005) summarized the differences between the two former institutions as indicated in Table 1.

The merger was part of a national higher education transformation process where 36 higher education institutions merged into 21. For this process, specific merger guidelines were used, including the prescription that the merger negotiations should be in equal partnership (Ministry of Education 2003), in order to minimize the possibilities of a "take-over" by the stronger institutions in the mergers. The former institution A had at the time of the merger approximately 32000 students, while the former institution B had approximately 9000 students in total (Anon. 2004: 3). In the year of the merger the former institution A delivered close to 6000 graduates and the former institution B approximately 1200 (Anon. 2004: 3). The total population (N) of the merged HEI was 2530 at the time of the formal merger. This population can be divided into two sub-populations, associated with the two pre-merger universities $\left(\mathrm{N}_{\mathrm{A}}=1650\right.$; $\left.\mathrm{N}_{\mathrm{B}}=880\right)$. A stratified random sample $(\mathrm{n}=1200)$ was used $\left(\mathrm{n}_{\mathrm{A}}=700 ; \mathrm{n}_{\mathrm{B}}=500\right)$, incorporating all levels of personnel in both academic and support positions in all the workplaces of the merged HEI who were already employed before the formal merger. A response rate of $42.6 \%$ was achieved, of which 492 responses $(96.3 \%)$ could be utilized $\left(\mathrm{nr}_{\mathrm{A}}=301 ; \mathrm{nr}_{\mathrm{B}}=191\right)$. 
Table 1: Employment relationship characteristics of the former institutions (Linde/Schalk 2005)

\begin{tabular}{|l|l|l|}
\hline Internal influence & \multicolumn{1}{|c|}{ Former institution A } & \multicolumn{1}{|c|}{ Former institution B } \\
\hline $\begin{array}{l}\text { Personnel demography } \\
\text { (excluding temporary } \\
\text { employees) }\end{array}$ & $\begin{array}{l}1650 ; 35 \% \text { academic, 65\% other } \\
\text { Generally alumni of institution }\end{array}$ & $\begin{array}{l}880 ; 27 \% \text { academic, 73\% other } \\
\text { Mainly recruited from other institu- } \\
\text { tions }\end{array}$ \\
\hline Union activity & $\begin{array}{l}\text { Organized; three recognized uni- } \\
\text { ons with two recognition agree- } \\
\text { ments }\end{array}$ & $\begin{array}{l}\text { Organized; one recognized majori- } \\
\text { ty union with agency-shop agree- } \\
\text { ment }\end{array}$ \\
\hline Referred disputes & $\begin{array}{l}35 ; 28 \text { unfair dismissal and practi- } \\
\text { ce } \\
(1: 48 \text { per capita ratio) }\end{array}$ & $\begin{array}{l}53 ; 47 \text { unfair dismissal and practi- } \\
\text { ce } \\
(1: 17 \text { per capita ratio) }\end{array}$ \\
\hline $\begin{array}{l}\text { Employment regulati- } \\
\text { ons } \\
\text { (agreements, policies, } \\
\text { codes \& procedures) }\end{array}$ & $\begin{array}{l}8: \text { disciplinary procedure, grievan- } \\
\text { ce procedure, remuneration policy, } \\
\text { intellectual property policy, perfor- } \\
\text { mance appraisal procedure, recru- } \\
\text { itment policy, dispute resolution } \\
\text { agreement, handling of poor work } \\
\text { performance policy }\end{array}$ & $\begin{array}{l}2: \text { night-work policy, retrenchent } \\
\text { policy }\end{array}$ \\
\hline Management structure & $\begin{array}{l}\text { Decentralized partially autonomous } \\
\text { Key management positions stable }\end{array}$ & $\begin{array}{l}\text { Centralized line-management } \\
\text { Key management position vacant } \\
\text { or temporary }\end{array}$ \\
\hline
\end{tabular}

\section{Measures}

Several self-reporting measuring instruments included in a questionnaire were applied:

- The psychological contract. The Tilburg Psychological Contract Questionnaire (TPC) contains questions on specific employer (43 items) and employee (21 items) obligations, as perceived by the employee (Schalk et al. 2001). Previous studies using this questionnaire provide support for the validity and reliability of the scales used (Schalk et al. 2001).

- Job insecurity. The Job Insecurity Questionnaire (De Witte 1999) includes 11 items relating to job insecurity, including both the possibility of becoming unemployed (cognitive assessment) and the emotional experience of the possible threatening situation (emotional reaction towards it). Previous studies using this questionnaire provide support for the validity and reliability of the scales used (De Witte 1999; Hellgren et al. 1999).

- Job satisfaction. The Minnesota Satisfaction Questionnaire (MSQ - short version) has 20 items, grouped into two dimensions, including intrinsic and extrinsic job satisfaction (Weiss 1967). The MSQ is used to measure how participants feel toward their job, with which aspects they are satisfied and with which they are not (Spector 1997). Previous studies using this questionnaire provide support for the validity and reliability of the scales used (Bagotti et al. 1991; Hirschfeld 2000; Rothmann 2002).

- Mental health. The GHQ-28, a 28-item scaled version of the original General Health Questionnaire (GHQ), was used. Four subscales, including somatic symptoms, anxiety and insomnia, social dysfunction, and severe depression, were derived by factor analysis (Goldberg/Hillier 1979). The validity of the subscales is 
discussed in Goldberg et al. (1997). The four subscales represent dimensions of symptomatology; thus more symptoms result in a higher score, but high scores do not necessarily correspond to any psychiatric diagnosis (Al-Hussaini et al. 2001).

- Influence of the merger. An additional self-report questionnaire (eight items) was developed, measuring the influence of the merger on the experience of the employment regulations, employer and employee obligations, job insecurity, job satisfaction, and general health.

\section{Design and procedure}

The study was conducted one year after the formal merger of the two institutions into the new HEI. Although structural merging of human resource-related policies and procedures had already been negotiated and implemented, in the form of an integrated general employment contract and recognition agreements, some consequences of the merger were still taking place and changes being implemented. The study was crosssectional. The questionnaire was mailed (via the internal post system of the HEI) to the participants, with a cover-letter and clear instructions, as well as an addressed envelope. Anonymity was applied in the process of collection. Since organized sessions for completion could not be implemented, the response rate was relatively low $(42.6 \%)$. Feedback on the response indicated that the length of the total questionnaire contributed to the low feedback. This was expected and a high percentage of the population $(47.4 \%)$ was used as the sample size to assure sufficient response.

\section{Results}

Factor analyses were done on the various parts of the questionnaire, except the GHQ28. The structure in the original language of the measures is for the most part comparable with this paper's results. With respect to Employer Obligations (part of the psychological contract questionnaire), two internally consistent factors were extracted. The first factor was Employee function (15 items) and covered mainly the perceived right to perform a function in the organization. These items included responsibility, training opportunities, reimbursement of own costs and taking initiative. The second factor was labeled Employer support (10 items) and relates to structural support for the employee to achieve full performance and development of the employee. Examples of items that loaded under this factor are management feedback, appreciation, efficient organization and colleague support. With respect to the second construct of the psychological contract questionnaire, Employee Obligations, three internally consistent factors were extracted, including Performance (6 items), related to perceived promises made by the employee to the employer with respect to performance, Extra-role Behavior (4 items), including additional activities not directly associated with the required duties of the employee, and Ethics ( 6 items), referring to perceived promises made to the employer by the employee, associated with ethical actions and loyalty to the organization.

The job insecurity questionnaire had three internally consistent factors, named Fear of Job Loss (4 items), referring to the cognitive assessment of possible job loss, Belief in Continuation of Job (4 items), an emotional assessment of job security, and Anxious of Job Loss ( 3 items), including the emotional experience of the possible threatening situation. 
The three factors associated with job satisfaction were Management Structures (8 items), referring to the respondents' satisfaction with the structure, Self-actualization (6 items), including the possibility of achieving optimum potential, and Autonomy (4 items), which refers to trust in accepting own responsibility without unnecessary management control.

The eight items associated with the questionnaire testing the respondents' experience of the merger were considered as individual items. As the first step in our analysis, we assessed whether there were statistically significant differences between the former institutions with respect to the dependent variable (experiencing the psychological contract, job satisfaction, job insecurity and general health). The results of the comparison identified a statistically significant difference between the groups $\left(F_{(4.651)}=\right.$ 47.74, $p<0.05$; Wilks' Lambda $=0.39$; partial eta squared $=0.61)$. One-way analyses of variance (ANOVA) were then used to test the differences between the two groups of respondents. All statistical analyses were conducted using SPSS for Windows. The results are given in Table 2 .

- Psychological contract. Statistically significant differences were reported on all the factors associated with the experience of the psychological contract. Respondents of former institution A experienced many fewer broken promises associated with employer obligations (employee function and employer support) than the respondents from the former institution B. Respondents from institution B, however, believed to have kept more promises made to the employer concerning performance, but fewer associated with extra-role behavior and ethics than their counterparts associated with institution A.

- Job insecurity. All three factors associated with the experience of job insecurity showed a large significant difference where institution A's respondents experienced higher levels of insecurity.

- Job satisfaction. Former institution B respondents experienced more job satisfaction associated with the management structures, while former institution A respondents experienced higher levels of job satisfaction associated with autonomy in the workplace.

- General health. The respondents from the former institution A experienced higher levels of symptoms associated with social dysfunction, while the respondents from the former institution B experienced significantly more severe depression.

- Influence of the merger. Respondents in a previous employment relationship with the pre-merged institution B experienced the influence of the merger on the employment relationship, clarity of the employment regulations, trust in the employment regulations, employer obligations, job insecurity and job satisfaction significantly more positively than the respondents associated with former institution A. In general, the majority of all the respondents of the merged HEI experienced the merger as positive $\left(\right.$ Mean $\left._{\text {total }}=3.066 ; 61.33 \%\right)$.

\section{Discussion}

How can we interpret these results? The objective of the present study was to identify how the employees experience their new employment relationship through the expe- 
rience of the psychological contract, job satisfaction, job insecurity and general health after the merger of public sector institutions. In addition, the study wanted to determine the influence of the merger on the experience of the psychological contract, job insecurity, job satisfaction and general health of employees with different previous employment relationships with the pre-merged institutions will be determined.

The employment contracts of the merged organization were based on two very different previous types of employment relationship of the pre-merged institutions. During the merger a new employment relationship was formed through a lengthy premerger negotiation process at top management level. The various and different conditions of employment, recognition agreements and other related policies were negotiated into a unified structure with the representative employee organizations. Even though the new employment relationship had already been implemented by the time this study was done, there was a very different experience of breach and violation of the psychological contract by respondents associated with the two former employment relationships, as indicated in Table 2. Linde and Schalk (2005) found that the institution $\mathrm{B}$ respondents perceived many more promises made to them by the employer $(97.2 \%)$ than did their counterparts $(84.5 \%)$. The high levels of breach and violation of employer obligations, as part of the psychological contract, perceived by the respondents of the former institution $\mathrm{B}$ can be attributed to the history of limited employment regulations in the former institution B. This implies that the post-merger employment relationship, with the same formal contract of employment and human resource policies, did not erase the history of unclear employer promises, as perceived by the employee.

Employees from the former institution B believe that they kept more promises made to the employer with respect to performance than did the institution A respondents. In contrast they perceived fewer promises associated with extra-role behavior and ethics. The pre-merged institution A performed significantly better in academic outcomes than the pre-merged institution $\mathrm{B}$, and the majority of support structures of institution A were used as benchmark for the new HEI, because of its previous successes (Anon. 2004; Institutional Negotiation Committee 2005).

An explanation is needed as to why the respondents of institution B believe they performed better in keeping their promises to the employer than the respondents from institution A, which achieved higher actual performance outcomes. As indicated in Table 1, a performance appraisal policy formed part of the management structure at institution A, while there was no similar policy at institution B. An explanation could be that the measurement of actual performance was better stipulated and controlled by institution $\mathrm{A}$ and that the respondents of institution $\mathrm{B}$ evaluated the performance promises they kept against other subjective standards.

The implementation of a standardized performance appraisal system at the merged HEI had been negotiated but had not yet been implemented when this study was done. Therefore an objective standard had not yet been established. As indicated before, performance goals of a merged organization are rarely met, something that has a very prominent effect on the perceived success of a merger. Assessing expectations about perceived performance obligations as part of the psychological contract before the merger could help establish achievable performance goals for the merger. In addi- 
tion, it could improve the planning of the intervention processes and identify performance standards that need to be addressed to relate actual individual performance with perceived individual performance.

The respondents of institution A experience significantly higher job insecurity than the institution B respondents. This is an unexpected result, since the annual labor turnover of institution A was significantly lower in the year before the merger. Labor disputes, associated with unfair dismissal and labor practices, were also much lower per capita at institution A than at institution B (as indicated in Table 1). The increased experience of job insecurity of respondents from institution A is probably more related to the merger than to the perception of an unstable employment relationship.

Another indication of this is the response on the influence of the merger on the experience of job insecurity (see Table 2): The respondents from institution B experienced the influence of the merger on their experience of job insecurity to be much better than their counterparts. The source of these higher levels of job insecurity experienced by respondents from institution A might be associated with the South African socio-political situation and the current approach to labor relations. The majority of employees associated with the former institution $\mathrm{A}$ are white, while the majority of respondents at the former institution $B$ are black. There is a focus on demographic representation in HEIs in South Africa, with its history of inequality. In the words of Reddy (2000: 79):

" $[\mathrm{H}]$ higher education participation rates of white and black students differ considerably, being $70 \%$ and $12 \%$ respectively. This is also reflected in human resources of HEIs, with $85.4 \%$ of permanently appointed academic staff at universities in 1997 being white and 7.4\% being black."

The respondents associated with institution A might fear that the merger would be used to address this inequality, which could have implications for them. The experience of the influence of the merger on job insecurity was also the item that had the lowest score among the respondents of institution $\mathrm{A}\left(\right.$ mean $_{\mathrm{A}}=2.4[48 \%]$; mean $_{\mathrm{B}}=3.32$ $[66.4 \%])$. Before the merger the management of institution A frequently informed the employees that the merger would not lead directly to retrenchments, a promise which was kept. The significant difference in the experience of job insecurity cannot be explained by deficiencies in communication before and during the merger. It is more likely that the general societal beliefs about the application of employment equity exerted an influence on the insecurity levels at the merged HEI. Another possible source of the high level of job insecurity could be the feeling that the stable pre-merged employment relationship associated with the former institution A might be threatened in the long run because of the merger.

The remuneration that the employees of institution $B$ received at the time of the merger was on average much higher (Joint Union Negotiation Committee 2004). The outputs of employees associated with the pre-merged institution A was, on the other hand, much higher. This might be the reason why the respondents of Institution B experienced higher levels of job satisfaction with respect to management structures (as indicated in Table 2): it benefited their input-output ratio. 
Table 2: Differences in the Psychological Contract, Job Satisfaction, Job Insecurity and General Health in the Different Previous Employment Relationships

\begin{tabular}{|c|c|c|c|c|c|c|c|c|c|c|c|c|c|c|}
\hline \multirow[t]{2}{*}{ Factor } & \multicolumn{4}{|c|}{$\begin{array}{c}\text { Institution A } \\
n=301\end{array}$} & \multicolumn{4}{|c|}{$\begin{array}{c}\text { Institution B } \\
n=191\end{array}$} & \multicolumn{6}{|c|}{$\begin{array}{c}\text { Total } \\
n=492\end{array}$} \\
\hline & Mean & Range & $\mathrm{SD}$ & $\alpha$ & Mean & Range & SD & $\alpha$ & $\mathrm{F}$ & $d f$ & $p$ & Range & SD & $\alpha$ \\
\hline $\begin{array}{l}\text { Psychological Contract } \\
\text { Employer Obligation }\end{array}$ & & & & & & & & & & & & & & \\
\hline Employee function & 51.14 & 72 & 13.47 & 0.87 & 46.64 & 51 & 12.15 & 0.89 & 14.055 & 1 & 0.00 & 72 & 13.143 & 0.87 \\
\hline $\begin{array}{l}\text { Employer support } \\
\text { Employee Obligation }\end{array}$ & 31.40 & 46 & 9.43 & 0.80 & 25.51 & 45 & 8.37 & 0.86 & 49.569 & 1 & 0.00 & 46 & 9.468 & 0.83 \\
\hline Performance & 20.40 & 30 & 4.75 & 0.72 & 24.62 & 16 & 3.12 & 0.77 & 118.301 & 1 & 0.00 & 30 & 4.673 & 0.74 \\
\hline Extra-role behavior & 14.15 & 20 & 3.88 & 0.65 & 12.32 & 17 & 3.50 & 0.76 & 27.664 & 1 & 0.00 & 20 & 3.840 & 0.70 \\
\hline $\begin{array}{l}\text { Ethics } \\
\text { Job Insecurity }\end{array}$ & 25.38 & 27 & 4.05 & 0.81 & 24.39 & 17 & 3.05 & 0.76 & 8.387 & 1 & 0.00 & 27 & 3.722 & 0.79 \\
\hline Fear of job loss & 15.24 & 16 & 3.71 & 0.82 & 13.93 & 16 & 5.00 & 0.89 & 11.023 & 1 & 0.00 & 16 & 4.300 & 0.86 \\
\hline Belief in continuation of job & 8.85 & 14 & 2.91 & 0.55 & 11.17 & 16 & 4.25 & 0.78 & 51.306 & 1 & 0.00 & 16 & 3.666 & 0.71 \\
\hline $\begin{array}{l}\text { Anxious of job loss } \\
\text { Job Satisfaction }\end{array}$ & 10.53 & 12 & 2.61 & 0.65 & 9.61 & 12 & 3.29 & 0.67 & 11.745 & 1 & 0.00 & 12 & 2.926 & 0.65 \\
\hline Management structures & 26.56 & 29 & 6.49 & 0.86 & 29.08 & 31 & 7.19 & 0.87 & 16.090 & 1 & 0.00 & 31 & 6.881 & 0.87 \\
\hline Self-actualization & 25.86 & 28 & 6.35 & 0.93 & 26.80 & 24 & 5.24 & 0.79 & 2.892 & 1 & $\mathrm{n} / \mathrm{s}$ & 28 & 5.947 & 0.87 \\
\hline $\begin{array}{l}\text { Autonomy } \\
\text { General Health }\end{array}$ & 16.36 & 15 & 3.05 & 0.83 & 14.58 & 12 & 3.13 & 0.46 & 38.997 & 1 & 0.00 & 15 & 3.194 & 0.72 \\
\hline Somatic symptoms & 11.79 & 17 & 3.87 & 0.87 & 11.64 & 21 & 4.09 & 0.84 & 0.168 & 1 & $n / s$ & 21 & 4.385 & 0.84 \\
\hline Anxiety and insomnia & 12.12 & 20 & 4.96 & 0.94 & 11.50 & 23 & 4.59 & 0.89 & 1.913 & 1 & $\mathrm{n} / \mathrm{s}$ & 23 & 5.529 & 0.92 \\
\hline Social dysfunction & 13.81 & 18 & 3.76 & 0.90 & 12.92 & 19 & 4.49 & 0.89 & 5.627 & 1 & 0.00 & 19 & 4.080 & 0.89 \\
\hline $\begin{array}{l}\text { Severe depression } \\
\text { Influence of Merger on: }\end{array}$ & 8.87 & 12 & 3.12 & 0.90 & 11.34 & 21 & 5.38 & 0.93 & 41.577 & 1 & 0.00 & 21 & 4.314 & 0.92 \\
\hline Employment relationship & 2.84 & 4 & 0.93 & - & 3.38 & 4 & 1.28 & - & 26.363 & 1 & 0.00 & 4 & 1.121 & - \\
\hline $\begin{array}{l}\text { Clarity of employment } \\
\text { regulations }\end{array}$ & 3.06 & 4 & 0.85 & - & 3.41 & 4 & 1.22 & - & 13.272 & 1 & 0.00 & 4 & 1.034 & - \\
\hline $\begin{array}{l}\text { Trust in employment } \\
\text { regulations }\end{array}$ & 2.45 & 4 & 1.02 & - & 3.34 & 4 & 1.22 & - & 70.876 & 1 & 0.00 & 4 & 1.188 & - \\
\hline Employer obligations & 2.97 & 4 & 0.85 & - & 3.54 & 4 & 1.23 & - & 34.416 & 1 & 0.00 & 4 & 1.059 & - \\
\hline Employee obligations & 3.41 & 3 & 0.85 & - & 3.42 & 4 & 1.16 & - & 0.025 & 1 & $\mathrm{n} / \mathrm{s}$ & 4 & 0.992 & - \\
\hline Job insecurity & 2.40 & 4 & 0.78 & - & 3.32 & 4 & 1.26 & - & 54.632 & 1 & 0.00 & 4 & 1.010 & - \\
\hline Job satisfaction & 2.95 & 4 & 0.75 & - & 3.32 & 4 & 1.29 & - & 14.705 & 1 & 0.00 & 4 & 1.027 & - \\
\hline General health & 2.94 & 4 & 0.51 & - & 3.10 & 4 & 1.10 & - & 4.621 & 1 & $\mathrm{n} / \mathrm{s}$ & 4 & 0.813 & - \\
\hline
\end{tabular}


According to South African labor law, the conditions of employment that the employee received at the time of a merger (including the remuneration packages), had to be the minimum conditions associated with the merged organization, unless negotiated otherwise (Grogan 2003). This protection of rewards might have helped maintain the positive experience of job satisfaction. The former institution A's higher job satisfaction associated with autonomy can be attributed to the minimum changes in performance and task appraisals after the merger. These types of policies were already in place at institution A before the merger. Therefore no managerial changes were necessary to implement it at that workplace, which may cause the experience of less autonomy in the workplace.

Furthermore, filling the key management positions that were vacant before the merger (as indicated in Table 1) addressed a shortage of management processes, which may have influenced the experience of autonomy. The average total job satisfaction experienced at the merged HEI is $78.8 \%$, quite a high level. The challenge for management of the merged HEI is to change the performance-remuneration discrepancies, without negatively influencing the satisfactory job satisfaction levels that the employees experience.

Table 2 indicates a significantly higher experience of social dysfunction at premerged Institution A, and severe depression at former institution B, which can be related to different stressors experienced at the various workplaces, and the previous pre-merged employment relationships. It must be mentioned that the significantly different non-psychiatric disorders, identified in Table 2, can be a direct consequence of workplace-related stress, even though this paper did not focus on the identification of such strain-related sources.

The significantly more positive experience of the influence of the merger, in general, by the respondents from institution B (as indicated in Table 2) is in line with findings of Terry et al. (1996), as well as Panchal and Cartwright (2001). These researchers used social identity theory to explain that a merger offers the less dominant partner (here pre-merged institution B) an opportunity to improve social identity, while undermining that of the more dominant partner (pre-merged institution $A$ ).

Our findings are different from the majority of past research examining group differences in mergers, which discovered negative outcomes for the less dominant partner (see Panchal/Cartwright 2001). In addition to the mentioned reason for this significantly more positive experience by respondents of institution $\mathrm{B}$ is the protection that these respondents experienced from the government (in promising equal partnership in the merger process) and the motivation for the mergers itself (to enhance the higher education landscape in South Africa). Even though institution A respondents experienced a significantly lower positive influence of the merger, the average experience was still positive, but much less than in the case of their institution B counterparts $\left(\operatorname{Mean}_{\mathrm{A}}=2.88[57.55 \%] ;\right.$ Mean $\left._{\mathrm{B}}=3.35[67.08 \%]\right)$.

The above results and discussion indicate how a very different experience of the psychological contract, job insecurity, job satisfaction and general health come into being. It explains differences between employees that were associated with different previous employment relationships before the merger, which had occurred one year 
after the actual merger in the process of establishing a new employment structure. These employment-related experiences have an important influence on work wellness and the productivity of employees. To develop a common employment relationship, including the above-mentioned employee experiences, to manage an organizational or institutional transformation process such a merger or acquisition successfully, the importance of the previous employment relationship should be taken into account. Assessing the experience of the psychological contract, job insecurity and satisfaction, as well as general health, of the employees before the actual merger process can identify significant differences that need to be addressed for the purpose of a successful organizational or institutional transformation.

\section{References}

Adams, C./Neely, A. (2000): The performance prism to boost M\&A success. In: Measuring Business Excellence, 4: 19-23.

Al-Hussaini, A./Dorvlo, A.S.S./Antony, S.X./Chavan, D./Dave, J./Purecha, V./Al-Rahbi, S./Al-Adawi, S. (2001): Vipassana meditation: a naturalistic, preliminary observation in Muscat. In: Medical Sciences, 3: 87-92.

Anon. (2004): Most progressive technological[ly] [sic] innovative university. Http://www.puk.ac.za/opencms/export/PUK/html/puk/NWU_Corporate.pdf

Bagotti, R.P./Phillips, L.W./Yi, Y. (1991): Assessing Construct Validity in Organizational Research. In: Administrative Science Quarterly, 36: 31-45.

Balmer, M.T./Dinnie, K. (1999): Corporate identity and corporate communications: the antidote to merger madness. In: Corporate Communications: An International Journal, 4: 182-192.

Baxier, M.M./Bogardus, A./Oldham, T. (2001): Why mergers fail. The McKinsey Quarterly, 4: 6-10.

Bert, A./MacDonald, T./Herd, T. (2003): Two merger integration imperatives: urgency and execution. In: Strategy and Leadership, 31: 42-49.

Cartwright, S./Cooper, C.L. (1996): Coping in occupational settings. In: M. Zeidner/N.S. Endler (Eds.), Handbook of coping: Theory, research, applications. Oxford: John Wiley \& Sons: 202-220.

Classe, A. (2004): Against human nature. In: Accountancymagazine.com, May: 32-33.

De Witte, H. (1999): Job insecurity and psychological well-being: Review of the literature and exploration of some unresolved issues. In: European Journal of Work and Organizational Psychology, 8: 155-177.

Galpin, T./Herndon, M. (2000): The complete guide to mergers and acquisitions. San Francisco: JosseyBass Inc.

Garrow, V. (2003): Pact to the future. In: People Management, Dec, 18: 26-30.

Goldberg, D./Hillier, V.F. (1979): A scaled version of the General Health Questionnaire. In: Psychological Medicine, 6, 565-569.

Goldberg, D.P./Gater, R./Sartorius, N./Ustun, T.B./Piccinelli, M./Gureje, O./Rutter, C. (1997): The validity of two versions of the GHQ in the WHO study of mental illness in general health care. In: Psychol Med, 27: 191-197.

Grogan, J. (2003): Workplace law (7th ed.). Kenwyn: Juta.

Hackett, M.C. (1996): Are there alternatives to a merger? In: Health Manpower Management, 22: 5-12.

Hirschfeld, R.R. (2000): Does Revising the Intrinsic and Extrinsic Subscales of the Minnesota Satisfaction Questionnaire Short Form Make a Difference? In: Educational and Psychological Measurement, 60: 255-270.

Hellgren, J. (2003): The times they are a-changin': Job uncertainty and the flexible labor market. Edsbruk: Akademitryck.

Hellgren, J./Sverke, M./Isaksson, K. (1999): A two-dimensional approach to job insecurity: consequences for employee attitudes and well-being. In: European Journal of Work and Organizational Psychology, 8: 179-195.

Huang, C.T.W./Kleiner, B.H. (2004): New developments concerning managing mergers and acquisitions. In: Management Research Review, 27: 54-62. 
Institutional Negotiation Committee. (2005): Minutes approved at the Institutional Negotiation Committee meeting, 1, Feb, 3.

International Merger and Acquisition Summit. (2003): Thesis collection: International M\&A summit Beijing. www.masummit.org

Joint Union Negotiation Committee. (2004): Minutes approved at the Joint Union Negotiation Committee meeting, 2, Feb, 5.

Katz, D. \& Kahn, R.L. (1978): The social psychology of organizations. (2nd ed.) New York: Wiley.

Kode, G.V.M./Ford, J.C./Sutherland, M.M. (2003): A conceptual model for evaluation of synergies in mergers and acquisitions: a critical review of the literature. In: South African Journal of Business Management, 31: 27-38.

Kotecha, P./Harman, G. (2001): Exploring institutional collaboration and mergers in higher education. Pretoria: SAUVCA.

Linde, B.J./Schalk, R. (2005): The influence of prior employment relations on the experience of the psychological contract: a South African case study. Paper presented at the biannual Dutch HR Conference, Enschede, The Netherlands.

Maree, J.G./Eiselen, R.J. (2004): The emotional intelligence profile of academics in a merger setting. In: Education and Urban Society, 36: 482-504.

Ministry of Education. (2003): Higher education restructuring and transformation: guidelines for mergers and incorporations. Pretoria: Government Printer.

Morrison, E.W./Robinson, S.L. (1997): When employees feel betrayed: A model of how psychological contract violation develops. In: Academy of Management Reviews, 1, 226-256.

Panchal, S./Cartwright, S. (2001): Group differences in post-merger stress. In: Journal of Managerial Psychology, 16: 424-433.

Porter, S.S./Kraft, F.B./Claycomb, C. (2003): The practice of a wellness lifestyle in a selling environment: a conceptual exploration. In: Journal of Personal Selling and Sales Management, 23: 191-204

Reddy, J. (2000): Regional consortia, partnerships, mergers and implications for the transformation of the South African higher education system. In: South African Journal of Higher Education, 14, 97-87.

Rothmann, S. (2002): Burnout research in South Africa. Paper presented at the $1^{\text {st }}$ South African Conference on Burnout, Potchefstroom, South Africa.

Rousseau, D.M. (1995): Psychological contracts in organizations: Understanding written and unwritten agreements. Thousand Oaks, CA: Sage.

Schalk, R./Heinen, J./Freese, C. (2001): Do organizational changes impact the psychological contract and workplace attitudes? A study of a merger of two home care organizations in the Netherlands. In: J. De Jonge/P. Vlerick/A. Büssing/W.B. Schaufeli (Eds.), Organizational psychology and health care at the start of a new millennium. Mering: Rainer Hampp Verlag: 23-38.

Schraeder, M./Self, D.R. (2003): Enhancing the success of mergers and acquisitions: an organizational culture perspective. In: Management Decision, 41: 511-522.

Spector, P.E. (1997): Job Satisfaction: Application, Assessment, Causes, and Consequences. Thousand Oaks: Sage Publications.

Stave, M.M./Muchmore, L./GardnerH. (2003): Quantifiable impact of the contract for health and wellness: health behaviors, health care costs, disability, and workers' compensation. In: Journal of Occupational \& Environmental Medicine. 45:109-117.

Terry, D.J./Callan, V.J./Sartori, G. (1996): Employee adjustment to an organizational merger: stress, coping and intergroup differences. In: Stress Medicine, 12: 105-122.

Vergnani, L. (2001): South Africa announces details of higher-education reform plan. In: The Chronicle of Higher Education, http://chora.virtualave.net/south-africa-reform.htm

Weiss, D.J. (1967): Manual for the Minnesota satisfaction questionnaire. Minneapolis: University of Minnesota.

Xundu, X. (2000): Task team integrates local council planning. In: Business Day: 5, Oct. 